\title{
$19: 54219405-54217939$
}

National Cancer Institute

\section{Source}

National Cancer Institute. 19: 54219405-54217939. NCI Thesaurus. Code C41955.

Physical location of CGB_Gene 